\title{
Program Görselleştirme Aracıyla Gerçekleştirilen Dijital Öyküleme Etkinliklerinin Yaratıcı Problem Çözme ve Bilgisayar Tutumuna Etkisi
}

\author{
Mutluhan Yılmaz *, Embiya Çelik ${ }^{* *}$
}

Makale Geliş Tarihi: 29/07/2020

Makale Kabul Tarihi: 09/11/2020

DOI: $10.35675 /$ befdergi. 775568

$\ddot{O} z$

Günümüzde üzerinde durulan becerilerden birisi Yaratıcı Problem Çözme becerisidir. Bu beceri Türkiye olarak ögrencilerimiz için geliştirilmesi gereken bir beceri olarak görülmektedir. Zira PISA 2015 sonuçlarına göre ülkemiz, yaratıcı problem çözme becerisi bakımından OECD ülkeleri içerisinde arzu edemeyeceğimiz bir yerdedir. Bu becerinin düşük olması, bireylerin karşılaştıkları sorunları çözmekte zorlanmalarına sebep olabilmektedir. Birçok araştırmacı için bilgisayar teknolojisi, ögrenme ve öğretmenin yollarını etkin şekilde destekleyen önemli bir araçtır. Bu doğrultuda, öğrencilerin bilgisayara karşı tutumu, bilgisayarı ögrenme aracı olarak kabul etmelerinde önem taşımaktadır. Bireylerin bilgisayara karşı olumlu tutum geliş̧tirmeleri, yaşamlarını kolaylaştıracağl gibi, oldukça önemli becerileri edinmelerini de kolaylaştıracaktır. Bu araştırmada Program Görselleştirme Aracı (Scratch) ile gerçekleştirilen dijital öyküleme etkinliklerinin öğrencilerin yaratıcı problem çözme becerisine (YPÇB) ve bilgisayara yönelik tutumlarına olan etkisi incelenmiştir. Çalı̧̧mada açılklayıcı desen tercih edilmiş; kolay ulaşılabilir örneklemle toplamda 61 katılımclyla çalışma yürütülmüşı̈̈r. Uygulanan programın ögrencilerin yaratıcı problem çözme becerisi ve bilgisayara yönelik tutumları üzerindeki kritik boyutlarda anlamlı bir farklılaşma sağladığ saptanmıştır.

Anahtar Kelimeler: Bilgisayara yönelik tutum, dijital öyküleme, scratch, yaratıcı problem çözme.

\section{The Effect of Digital Storytelling Activities On Creative Problem Solving and Attitude Towards Computer}

\begin{abstract}
Creative problem solving is one of the most deprivation experienced of our students. Because of Turkey in terms of creative problem-solving skill is below from the OECD average according to PISA 2015 results. This situation can cause individuals to have difficultly in solving the problems they face. For many researchers, computer technology is an important tool that effectively supports ways of learning and teaching. Accordingly, students' attitude

* Ostim Teknik Üniversitesi, Meslek Yüksekokulu, Bilgisayar Teknolojisi Bölümü, Ankara, Türkiye, mutluhan.yilmaz@ ostimteknik.edu.tr, ORCID: 0000-0002-4341-4196

** Atatürk Üniversitesi, Açıköğretim Fakültesi, Bilgisayar Kullanımı Bölümü, Erzurum, Türkiye, embiya82@ hotmail.com, ORCID: 0000-0002-6703-8578 (D)

Kaynak Gösterme: Çelik, E. \& Yılmaz, M. (2020). Program görselleştirme aracıyla gerçekleştirilen dijital öyküleme etkinliklerinin yaratıcı problem çözme ve bilgisayar tutumuna etkisi. Bayburt Eğitim Fakültesi Dergisi, 15(30), 458-481. https://doi.org/10.35675/befdergi.775568
\end{abstract}


towards computer is important. In this study, the effect of digital storytelling activities performed with the Program Visualization Tool (Scratch) on students' creative problem-solving skills and their attitudes towards the computer was examined. Descriptive model was preferred in the study; A easily accessible sample was selected and the study was carried out with 61 participants. It was determined that the applied program provided a significant difference in critical dimensions on students' creative problem-solving skills and attitudes towards Computer.

Keywords: Attitude towards the computer, creative problem solving, digital storytelling, scratch.

\section{Giriş}

Bilimsel ve teknolojik gelişmeler sayesinde dünya oldukça büyük değişimlere tanıklık etmektedir. Bu değişimler, hayatın her alanını en kesif biçimiyle etkilemektedir. Bu değişimlerden nasibini alan disiplinlerden birisi de hiç şüphesiz eğitimdir (Gülbahar, 2019). Eğitimin ve bileşenlerinin, yeni teknolojik ve bilimsel gelişmelerin etkisiyle biçimlendiği, yeni ve farklı arayışlara maruz kaldığı bir gerçektir.

Günümüzdeki neslin ihtiyaçları önceki nesillere göre farklılık gösterdiğinden, günümüz öğrencilerine önceki nesillerden daha farklı bir eğitim ortamı sağlamak gerekmektedir (Prensky, 2001). Zamane öğrencilerinin ihtiyaçlarını karşılamak, onlara daha etkin bir eğitim süreci deneyimletmek ve 21. yüzyılın yetkinliklerini kazandırmak için teknolojinin eğitim öğretim ortamlarında kullanımını gerekli kılmıştır. Teknolojinin sınıf içine taşınması, ders müfredatlarından kullanılan araç gereçlere değin birçok boyutta yenilik yaratmıştır. Yaşanan değişimler yeni yetişenlerden önceki nesillere göre teknolojik beceriler, bilgi teknoloji, medya ve bilgi okuryazarlığı gibi daha farklı yetkinlik bekleyişini beraberinde getirmiştir (Nelson, 2009). Eğitime bilimsel ve teknolojik boyut kazandırmanın zorunlu olduğu bir zamanda, eğitim ile teknolojinin süreç içerisindeki uyumunu test etmek ve geliştirmek oldukça önemli bir husustur (Alkan, 2011). Dolayısıyla eğitim öğretim ortamlarında kullanılan, bu ortamlara uyarlanan dijital aygıtların günlük hayatta her alanda sıklıkla kullanılması, alanda gerçekleştirilen araştırma eğilimlerini belirlemekte, araştırmalara yön vermektedir. Bu araştırmalar sonucunda birçok araştırmacı, eğitimde bilgi ve iletişim teknolojilerine entegre sağlamanın öğrencilerin düşüncelerini ve bilişsel süreç yeteneklerini geliştirdiğine inanmakta, bilgisayar teknolojisini, öğrenme ve öğretmenin yollarını etkin bir şekilde destekleyen önemli bir araç olarak görmektedir (Hooshyar, Binti Ahmad, Wang, Yousefi, Fathi \& Lim 2018; Wang \& Lin, 2018). Bu doğrultuda, öğrencilerin eğitim öğretim sürecinde kullanılan teknolojik aygitlara, özellikle bilgisayara karşı tutumu, bilgisayarı bir öğrenme aracı olarak kabul etmelerinde ve gelecekteki çalışmaları için bilgisayarı vazgeçilmez görmelerinde önemli bir role sahiptir. Bireylerin bilgisayara karşı olumlu bir tutum geliştirmeleri, şimdiki ve gelecekteki sosyal ve mesleki yaşamlarını kolaylaştıracağı gibi, bireylerin oldukça önemli becerileri edinmelerini de kolaylaştıracaktır (Peng, 2017). Bunun yanı sıra günümüzde pek çok otorite tarafindan üzerinde durulan becerilerden birisi 
Yaratıcı Problem Çözme becerisidir. Bu beceri Türkiye olarak pek çok ulusal veya PISA gibi uluslararası sinavlarda öğrencilerimizin en fazla yoksunluk yaşadığı becerilerden biri olarak ön plana çıkmaktadır. Problem çözme becerisinin düşük olması, problemlere farklı ve yaratıcı açılardan çözüm yolu geliştirilememesi bireylerin karşılaştıkları sorunları çözmekte zorlanmalarına sebep olabilmektedir (OECD, 2017).

Buradan hareketle, program görselleştirme aracıyla (Scratch) gerçekleştirilen eğitimde son zamanların trendlerinden olan dijital öyküleme etkinliklerinin (Sadik, 2008) yaratıcı problem çözme becerisi ve bilgisayara yönelik tutum üzerindeki etkisi incelenmiştir.

Bu kapsamda öğrencilere İngilizce dersinde müfredata uygun ve müfredatı takiben işlenen konunun kazanımlarını önce Storyboard olarak adlandırdığımız kâğıt üzerine resmetmesini, ardından aynı kazanımlar doğrultusunda benzer çalışmayı program görselleştirme aracıyla dijital öyküleme etkinliği şeklinde yapmasını temel alan bir çalışma gerçekleştirilmiş, aşağıdaki araştırma sorularına cevap aranmıştır.

1. Program görselleştirme aracıyla (Scratch) gerçekleştirilen dijital öykülemenin öğrencilerin yaratıcı problem çözebilme becerisi üzerinde etkisi var mıdır?

- Öğrencilerin sınıf düzeyine göre yaratıcı problem çözme becerisi öntestsontest puanları arasında anlamlı farklılık var mıdır?

- Öğrencilerin cinsiyetine göre yaratıcı problem çözme becerisi öntest-sontest puanları arasında anlamlı farklılık var midır?

2. Program görselleştirme aracıyla (Scratch) gerçekleştirilen dijital öykülemenin öğrencilerin bilgisayara yönelik tutumu üzerinde etkisi var mıdır?

- Öğrencilerin öntest-sontest puanları sınıf düzeyine göre farklılaşmakta mıdır?

- Öğrencilerin öntest-sontest puanları cinsiyetlerine göre farklılaşmakta mıdır?

3. Öğrencilerin program görselleştirme aracıyla (Scratch) programlamaya dair görüşleri nelerdir?

- Öğrencilerin dijital öyküleme yaparken Scratch programının kullanımına yönelik görüşleri nelerdir?

- Dijital öyküleme tekniğinin Scratch ile programlamaya etkisi nasıldır?

Yöntem

Araştırma hem nicel hem de nitel yöntemi esas alan karma bir yöntem zemininde yürütülmüştür. Araştırmada karma araştırma yöntemlerinden açıklayıcı desen tercih edilmiştir. Açıklayıcı desen, bir yöntemin başarısına dair yürütülen bir çalışmada öğrenci başarıları kıyaslandıktan sonra yöntemlere dair en çok beğenilen boyutların öğrenci görüşmeleriyle ortaya konduğu desendir (Büyüköztürk, Çakmak, Akgün, Karadeniz \& Demirel, 2016). Araştırmanın nicel boyutunu zayıf deneysel desen 
oluşturmaktadır. Bu doğrultuda çalışmada tek grup öntest-sontest yaklaşımı tercih edilmiştir. $\mathrm{Bu}$ yaklaşımda, deneysel işlemin tesiri bir tek grup üzerinde gerçekleştirilen çalışmayla sınanır (Büyüköztürk vd., 2016). Bunun yanı sıra görüşme süreciyle de nitel veriler elde edilmiştir. Dolayısıyla çalışma hem nitel hem de nicel verilerin bir arada olduğu karma bir çalışma olarak ön plana çıkmıştır.

Ayrıca bu çalışmada yazarların etik kurallara bağlılığını gösterir rapor, ilgili üniversitenin Eğitim Bilimleri Birim Etik kurulunun 06.05.2020 tarihli toplantıda alınan 12 nolu kararla belgelenmiştir.

\section{Katılımcılar}

Araştırmada, bir doğu ilimizin üniversitesine bağlı vakıf okullarında kayıtlı 6 . ve 7 . Sınıf öğrencisi olmak üzere toplamda 61 katılımcı yer almıştır. Katılımcılara dair demografik bilgi Tablo 1'de yer almaktadır.

Tablo 1.

Örneklem Grubunda Yer Alan Öğrencilerin Demografik Bilgileri

\begin{tabular}{llll}
\hline Sinıf & Cinsiyet & $\mathrm{f}$ & $\%$ \\
\hline \multirow{2}{*}{ 6. Sinıf } & Kiz & 14 & 22.96 \\
& Erkek & 14 & 22.96 \\
\hline \multirow{2}{*}{ 7. Sinıf } & Kiz & 16 & 26.22 \\
& Erkek & 17 & 27.86 \\
& Toplam & 61 & 100 \\
\hline
\end{tabular}

\section{Veri Toplama ve Analiz Etme Yöntemi}

Veri toplama aracı olarak öğrencilerin yaratıcı problem çözme becerilerini ölçmek için Iraksak Düşünme, Yakınsak Düşünme, Motivasyon, Çevre ve GBB (Genel Bilgi Beceriler) olmak üzere 5 alt boyuttan oluşan, Lin (2010) tarafindan geliştirilen ve Baran-Bulut, İpek ve Aygün (2018) tarafindan Türkçeye uyarlanan Yaratıcı Problem Çözme Özellikleri Envanteri; Bilgisayardan Hoşlanma, Bilgisayarın Önemi ve Bilgisayar Kaygısı olmak üzere 3 alt boyuttan oluşan Bilgisayara Yönelik Tutum becerilerini ölçmek içinse, Teo (2008) tarafindan geliştirilen ve Demir ve Yurdugül (2014) tarafindan Türkçeye uyarlanan Ortaokul ve Lise Öğrencileri İçin Bilgisayara Yönelik Tutum Ölçeği kullanılmıştır. Her iki ölçeğin hedef kitleye uygunluğu, geçerlik ve güvenirlikleri onanmış, kullanım için geliştiricilerden gerekli izin alınmıştır.

Elde edilen nicel veriler SPSS programı yardımıyla analiz edilmiştir. Beşli Likert Tipi formatına sahip olan Yaratıcı Problem Çözme Özellikleri Envanteri ve Ortaokul ve Lise Öğrencileri için Bilgisayara Yönelik Tutum Ölçeği ile toplanan öntest-sontest verileri SPSS programına aktarılarak normallik testleri, Bağımlı örneklem T testi, Bağımsız Örneklem T-testi ve non-parametrik testler ile analizi sağlanmış ve yorumlanmıştır. 
Nitel veriler içinse yarı yapılandırılmış görüşme formu kullanılmıştır. Görüşme formu araştırmacı tarafından öğrencilerin uygulamalara yönelik görüşlerini ortaya çıkarabilecek nitelikte geliştirilmiştir. Alan uzmanı ve dil uzmanı tarafından kontrol edilen görüşme formuna son hali verilerek öğrencilerle yaklaşık 10 dakika süren görüşmeler yapılmıştır. Bu görüşmelerin tamamı transkript edilerek betimsel analiz yöntemiyle analiz edilmiştir.

\section{Süreç}

Uygulama; toplamda 61 öğrenciye uygulama hakkında genel bilgilendirmeler verilmesi, Robin (2015)' in belirttiği gibi dijital öykülemenin dört adımı anlatılmış ve Scratch programının kullanımına yönelik eğitimlerle başlamış; Yaratıcı Problem Çözme Özellikleri Envanteri ile Ortaokul ve Lise Öğrencileri İçin Bilgisayara Yönelik Tutum Ölçeği öntest olarak uygulanması ile ilk etabı tamamlanmıştır.

Ardından 5 hafta boyunca Scratch programı aracılığıyla dijital öyküleme tekniği kullanılarak Yabancı Dil dersinin müfredatını takiben o hafta işlenen konuların öyküleme çalışmaları yapılmış, toplamda 10 uygulama ile süreç tamamlanmıştır. Öyküleme etabı ilgili konunun ilk olarak Storyboard olarak kabul edilen boş bir kağıda resmedilmesiyle başlamış, ardından Scratch ortamında aynı temadaki öykülemeyle tamamlanmıştır. Robin (2015)'e göre dijital öyküleme süreci Şekil 1 'deki gibi dört boyuttan oluşmaktadır:

Tanımlama,

biriktirme ve

karar verme
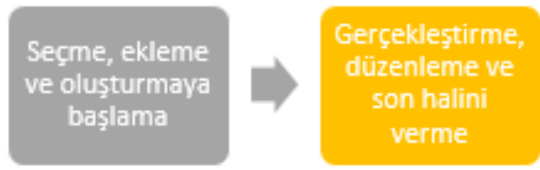

Oynatma ve

Değerlendirme

Şekil 1. Dijital öyküleme süreci

\section{Bulgular ve Yorum}

$\mathrm{Bu}$ kısımda araştırma soruları 1şığında elde edilen bulgulara yer verilmiştir.

\section{Yaratıcı Problem Çözme Öntest-Sontest Sonuçları}

Scratch ile Gerçekleştirilen Dijital Öyküleme Etkinliklerinin Öğrencilerin Yaratıcı Problem Çözebilme Becerisi Üzerinde Etkisi Var Mıdır? Sorusu için hangi testlerin kullanılacağına dair normallik testi yapılmıştır. Ortaya çıkan normallik testinin sonuçları Tablo 2'de verilmiştir. 
Tablo 2.

Normallik Testi

\begin{tabular}{lccccccc}
\hline & \multicolumn{3}{c}{ Kolmogorov-Smirnov } & \multicolumn{3}{c}{ Shapiro-Wilk } \\
\hline & Statistic & $\mathrm{N}$ & $\mathrm{p}$ & Statistic & $\mathrm{N}$ & $\mathrm{p}$ \\
\hline Yaratıcı Problem Çözme Becerisi Öntest & .105 & 61 & .094 & .965 & 61 & .075 \\
\hline Yaratıcı Problem Çözme Becerisi Sontest & .101 & 61 & .199 & .978 & 61 & .333 \\
\hline
\end{tabular}

Tablo 2'deki verilere göre Yaratıcı Problem Çözme Becerisi ölçeğiyle elde edilen verilerin normal dağılım gösterdiği söylenebilir $(\mathrm{p}>0.05)$. Bu sonuçtan hareketle testin analizi için parametrik test olan bağımlı t-testi uygulanmıştır. Bağımlı t-testine dair veriler Tablo 3 'te sunulmuştur.

Tablo 3.

Öğrencilerin Yaratıcı Problem Çözme Envanterine ve Alt Boyutlarına İlişkin ÖntestSontest Puanlarının Bağımlı Örneklem T-Testi Sonuçları

\begin{tabular}{|c|c|c|c|c|c|c|c|}
\hline Ölçek & Test Puan & $\mathrm{N}$ & $X$ & Ss & $\mathrm{T}$ & sd & $\mathrm{p}$ \\
\hline \multirow[t]{2}{*}{ Iraksak düşünme } & Öntest & 61 & 35.29 & 6.60 & \multirow[t]{2}{*}{-2.00} & \multirow[t]{2}{*}{60} & \multirow[t]{2}{*}{.049} \\
\hline & Sontest & 61 & 37.31 & 6.83 & & & \\
\hline \multirow{2}{*}{ Yakınsak Düşünme } & Öntest & 61 & 28.44 & 5.70 & \multirow{2}{*}{-5.90} & \multirow{2}{*}{60} & \multirow{2}{*}{.000} \\
\hline & Sontest & 61 & 33.81 & 5.90 & & & \\
\hline \multirow{2}{*}{ Motivasyon } & Öntest & 61 & 20.88 & 4.61 & \multirow{2}{*}{-2.79} & \multirow{2}{*}{60} & \multirow{2}{*}{.007} \\
\hline & Sontest & 61 & 22.48 & 4.59 & & & \\
\hline \multirow{2}{*}{ Çevre } & Öntest & 61 & 41.61 & 10.37 & \multirow{2}{*}{.991} & \multirow{2}{*}{60} & \multirow{2}{*}{.325} \\
\hline & Sontest & 61 & 40.62 & 8.42 & & & \\
\hline \multirow{2}{*}{ GBB } & Öntest & 61 & 16.09 & 4.03 & \multirow{2}{*}{-.847} & \multirow{2}{*}{60} & \multirow{2}{*}{.400} \\
\hline & Sontest & 61 & 16.42 & 3.76 & & & \\
\hline \multirow{2}{*}{$\begin{array}{l}\text { Yaratıcı Problem } \\
\text { Çözme Becerisi }\end{array}$} & Öntest & 61 & 142.31 & 21.90 & \multirow{2}{*}{-3.63} & \multirow{2}{*}{60} & \multirow{2}{*}{.001} \\
\hline & Sontest & 61 & 150.66 & 22.95 & & & \\
\hline
\end{tabular}

Tablo 3 incelendiğinde bağımlı örneklem t testi sonuçlarına göre öğrencilerin Yaratıcı Problem Çözme Becerisi öntest başarı puanı ortalaması $(\bar{X}=142.31)$ ile sontest başarı puanı ortalaması $(\bar{X}=150.66)$ arasında sontest lehine istatistiksel olarak anlamlı bir farklılık görülmüştür $[\mathrm{t}(60)=-3.63, \mathrm{p}<.05]$.

Ölçeğin alt boyutlarındaki sonuçlara bakıldığında Iraksak Düşünme Öntest başarı puan ortalaması $(\bar{X}=35.29)$ ile sontest başarı puanı ortalaması $(\bar{X}=37.31)$ arasında sontest lehine istatistiksel olarak anlamlı bir farklılık görülmüştür $[\mathrm{t}(60)=-2.00$, $\mathrm{p}<.05]$.

Ölçeğin alt boyutlarındaki sonuçlara bakıldığında Yakınsak Düşünme Öntest başarı puan ortalaması $(\bar{X}=28.44)$ ile sontest başarı puanı ortalaması $(\bar{X}=33.81)$ arasında sontest lehine istatistiksel olarak anlamlı bir farklılık görülmüştür $[\mathrm{t}(60)=-$ $5.90, \mathrm{p}<.05]$. 
Ölçeğin Motivasyon alt testi sonuçlarına bakıldığında Motivasyon Öntest başarı puan ortalaması $(\bar{X}=20.88)$ ile sontest başarı puanı ortalaması $(\bar{X}=22.48)$ arasında sontest lehine istatistiksel olarak anlamlı farklılık dişa vurmuştur [t(60)=-2.79, $\mathrm{p}<.05]$.

Ölçeğin Çevre alt testi Öntest ve sontest puanları incelendiğinde öntest puan ortalaması $(\bar{X}=41.61)$ ile GBB sontest puan ortalaması $(\bar{X}=40.62)$ arasında istatistiksel olarak anlamlı bir farkl11ık bulunamamıştır [t(60)=.991 p>.05].

Ölçeğin GBB (Genel Bilgi Beceri) alt testi Öntest ve sontest puanları incelendiğinde GBB öntest puan ortalaması $(\bar{X}=16.09)$ ile GBB sontest puan ortalaması $(\bar{X}=16.42)$ arasında istatistiksel olarak anlamlı bir farklılık bulunamamıştır $[\mathrm{t}(60)=-, 847 \mathrm{p}>.05]$.

\section{Yaratıcı problem çözme becerisinin sınıf düzeyine göre analizi}

Öğrencilerin Sınıf Düzeyine göre Yaratıcı Problem Çözebilme Becerisi öntestsontest puanları arasında anlamlı farklılık var mıdır? Sorusunun yanıtı için öğrenciler 6. ve 7. Sınıflar olarak ayrılmış ve bağımsız örneklem t-testi kullanılarak analiz gerçekleştirilmiştir. Bağımsız örneklem t-testi sonuçları Tablo 4 'te verilmiştir.

Tablo 4.

6. ve 7. Sinıf Öğrencilerinin Yaratıcı Problem Çözme Öntest-Sontest Puanlarının Bă̆ımsız Örneklem T-Testi Sonuçları

\begin{tabular}{|c|c|c|c|c|c|c|c|}
\hline Değişken & Grup & $\mathrm{N}$ & $X$ & ss & $\mathrm{t}$ & $\mathrm{sd}$ & $\mathrm{p}$ \\
\hline \multirow{2}{*}{$\begin{array}{l}\text { Iraksak düşünme } \\
\text { öntest puanı }\end{array}$} & 6. Sinif & 28 & 34.15 & 4.93 & \multirow[t]{2}{*}{-1.24} & \multirow[t]{2}{*}{59} & \multirow[t]{2}{*}{.097} \\
\hline & 7.Sinıf & 33 & 36.25 & 7.68 & & & \\
\hline \multirow{2}{*}{$\begin{array}{l}\text { Yakınsak düşünme } \\
\text { öntest }\end{array}$} & 6. Sinif & 28 & 27.08 & 5.51 & \multirow{2}{*}{-1.73} & \multirow{2}{*}{59} & \multirow{2}{*}{.712} \\
\hline & 7.Sinıf & 33 & 29.59 & 5.69 & & & \\
\hline \multirow{2}{*}{ Motivasyon öntest } & 6. Sinif & 28 & 20.28 & 4.49 & \multirow{2}{*}{-.937} & \multirow{2}{*}{59} & \multirow{2}{*}{.870} \\
\hline & 7.Sinif & 33 & 21.39 & 4.72 & & & \\
\hline \multirow{2}{*}{ Çevre öntest } & 6. Sinif & 28 & 42.25 & 8.49 & \multirow{2}{*}{.447} & \multirow{2}{*}{59} & \multirow{2}{*}{.034} \\
\hline & 7. Sinif & 33 & 41.05 & 11.85 & & & \\
\hline \multirow{2}{*}{ GBB öntest } & 6. Sinif & 28 & 16.10 & 3.70 & \multirow{2}{*}{.029} & \multirow{2}{*}{59} & \multirow{2}{*}{.319} \\
\hline & 7. Sinif & 33 & 16.07 & 4.35 & & & \\
\hline \multirow{2}{*}{$\begin{array}{l}\text { Yaratıcı problem } \\
\text { çözme becerisi } \\
\text { öntest }\end{array}$} & 6. Sinif & 28 & 139.88 & 16.31 & \multirow[b]{2}{*}{-.796} & \multirow[b]{2}{*}{59} & \multirow[b]{2}{*}{.020} \\
\hline & 7. Sinif & 33 & 144.38 & 25.79 & & & \\
\hline \multirow{2}{*}{$\begin{array}{l}\text { Iraksak düşünme } \\
\text { sontest puanı }\end{array}$} & 6.Sinif & 28 & 36.07 & 7.02 & \multirow{2}{*}{-1.32} & \multirow{2}{*}{59} & \multirow{2}{*}{.827} \\
\hline & 7.Sinif & 33 & 38.37 & 6.57 & & & \\
\hline \multirow{2}{*}{$\begin{array}{l}\text { Yakınsak düşünme } \\
\text { sontest puanı }\end{array}$} & 6. Sinif & 28 & 33.21 & 6.15 & \multirow{2}{*}{-.732} & \multirow{2}{*}{59} & \multirow{2}{*}{.946} \\
\hline & 7.Sinif & 33 & 34.32 & 5.72 & & & \\
\hline \multirow{2}{*}{$\begin{array}{l}\text { Motivasyon } \\
\text { sontest }\end{array}$} & 6. Sinif & 28 & 22.79 & 4.22 & \multirow{2}{*}{.483} & \multirow{2}{*}{59} & 58 \\
\hline & 7.Sinıf & 33 & 22.22 & 4.92 & & & .584 \\
\hline Çevre sontest & 6. Sinif & 28 & 41.54 & 7.69 & .781 & 59 & .212 \\
\hline
\end{tabular}




\begin{tabular}{|c|c|c|c|c|c|c|c|}
\hline & 7.Sinif & 33 & 39.84 & 9.05 & & & \\
\hline \multirow{2}{*}{ GBB sontest } & 6. Sinıf & 28 & 15.90 & 3.29 & \multirow{2}{*}{-.984} & \multirow{2}{*}{59} & \multirow{2}{*}{.363} \\
\hline & 7. Sinıf & 33 & 16.86 & 4.11 & & & \\
\hline \multirow{2}{*}{$\begin{array}{l}\text { Yaratıcı problem } \\
\text { çözme becerisi } \\
\text { sontest }\end{array}$} & 6.Sinif & 28 & 149.53 & 21.89 & \multirow[b]{2}{*}{-.353} & \multirow[b]{2}{*}{59} & \multirow[b]{2}{*}{.631} \\
\hline & 7.Sinıf & 33 & 151.62 & 24.10 & & & \\
\hline
\end{tabular}

Tablo 4 incelendiğinde bağımsız örneklem t testi sonuçlarına göre Sınıf düzeyinde 6. Sınıf öğrencilerinin Iraksak Düşünme öntest başarı ortalaması $(\bar{X}=34.15)$ ile 7 . Sınıf öğrencilerinin Iraksak Düşünme öntest başarı ortalaması $(\bar{X}=36.25)$ arasında istatistiksel olarak anlamlı bir farklılık görülmemiştir [t(59)=-1.24, p>.05]. Dolayısıyla Iraksak Düşünme öntest puanı sınıf düzeyine göre herhangi bir farklılık göstermemektedir.

Bir diğer boyutta 6. Sınıf öğrencilerinin Yakınsak Düşünme öntest başarı ortalaması $(\bar{X}=27.08)$ ile 7. Sınıf öğrencilerinin Yakınsak Düşünme öntest başarı ortalaması $(\bar{X}=29.59)$ arasında istatistiksel olarak anlamlı bir farklılık görülmemiştir $[\mathrm{t}(59)=-1.73, \mathrm{p}>.05]$.

Motivasyon boyutunda 6 . Sınıf öğrencilerinin öntest başarı ortalaması $(\bar{X}=20.28)$ ile 7. Sınıf öğrencilerinin öntest başarı ortalaması $(\bar{X}=21.39)$ arasında istatistiksel olarak anlamlı bir farklılık ortaya çıkmamıştır $[\mathrm{t}(59)=-.937, \mathrm{p}>.05]$.

Ölçeğin Çevre alt boyutunun sinıf düzeyine göre analiz edilmesi sonucunda 6 . Sınıf öğrencilerinin öntest başarı ortalaması $(\bar{X}=42.25)$ ile 7 . Sınıf öğrencilerinin öntest başarı ortalaması $(\bar{X}=41.05)$ arasında istatistiksel olarak anlamlı bir farklılık görülmüştür[t(59)=.4477, $\mathrm{p}<.05]$.

GBB (Genel Bilgi Beceriler) alt boyutunun sınıf düzeyine göre analiz edilmesi neticesinde 6. Sınıf öğrencilerinin öntest başarı ortalaması $(\bar{X}=16.10)$ ile 7. Sınıf öğrencilerinin öntest başarı ortalaması $(\bar{X}=16.07)$ arasında istatistiksel olarak anlamlı bir farklılık ortaya çıkmamıştır [t(59)=-.029, p>.05].

Ölçeğin tamamını tanımlayan Yaratıcı Problem Çözme Becerilerinin sınıf düzeyine göre analizi sonucu 6. Sınıf öğrencilerinin öntest başarı ortalaması $(\bar{X}=$ 139.88) ile 7. Sınıf öğrencilerinin öntest başarı ortalaması $(\bar{X}=144.38)$ arasında istatistiksel olarak anlamlı bir farklılık ortaya çıkmıştır [t(59)=-.796, p<.05].

Iraksak Düşünme sontest verileri sınıf düzeyine göre analiz edildiğinde 6. Sınıf öğrencilerinin sontest başarı ortalaması $(\bar{X}=36.07)$ ile 7. Sınıf öğrencilerinin sontest başarı ortalaması $(\bar{X}=38.37)$ arasında istatistiksel olarak anlamlı bir farklılık ortaya çıkmamıştır [t $(59)=-1.37, \mathrm{p}>.05]$.

Yakınsak Düşünme sontest verilerinin sınıf düzeyine göre analiz edilmesi sonucu 6. Sınıf öğrencilerinin sontest başarı ortalaması $(\bar{X}=33.21)$ ile 7 . Sınıf öğrencilerinin 
sontest başarı ortalaması $(\bar{X}=34.32)$ arasında istatistiksel olarak anlamlı bir farklılık ortaya çıkmamıştır $[\mathrm{t}(59)=-.732, \mathrm{p}>.05]$.

Motivasyon boyutunun sontest verilerinin sınıf düzeyine bağlı olarak analizi sonucunda 6. Sınıf öğrencilerinin sontest başarı ortalaması $(\bar{X}=22.79)$ ile 7. Sınıf öğrencilerinin sontest başarı ortalaması $(\bar{X}=22.22)$ arasında istatistiksel olarak anlamlı bir farklılık ortaya çıkmamıştır $[\mathrm{t}(59)=.483, \mathrm{p}>.05]$.

Çevre boyutunun sontest veri setinin sınıf düzeyine bağlı olarak analiz edilmesiyle 6. Sınıf öğrencilerinin sontest başarı ortalaması $(\bar{X}=41.54)$ ile 7. Sınıf öğrencilerinin sontest başarı ortalaması $(\bar{X}=39.84)$ arasında istatistiksel olarak anlamlı bir farklılık ortaya çıkmamıştır [t(59)=.781, p>.05].

GBB (Genel Bilgi Beceriler) boyutunun sontest veri setinin sınıf düzeyine bağlı olarak analiz edilmesiyle 6. Sınıf öğrencilerinin sontest başarı ortalaması $(\bar{X}=15.90)$ ile 7. Sınıf öğrencilerinin sontest başarı ortalaması $(\bar{X}=16.86)$ arasında istatistiksel olarak anlamlı bir farklılık ortaya çıkmamıştır [t(59)=-.984, p>.05].

Ölçeğin tamamını ihtiva eden Yaratıcı Problem Çözme Becerilerinin sınıf düzeyine göre analizi sonucu 6. Sınıf öğrencilerinin sontest başarı ortalaması $(\bar{X}=$ 149.53) ile 7. Sınıf öğrencilerinin sontest başarı ortalaması $(\bar{X}=151.62)$ arasında istatistiksel olarak anlamlı bir farklılık ortaya çıkmamıştır [t(59)=-.353, p>.05].

\section{Yaratıcı problem çözme becerisinin cinsiyet düzeyine göre analizi}

Öğrencilerin Cinsiyete göre Yaratıcı Problem Çözme Becerisi Öntest- sontest puanları arasında anlamlı farklılık Var Mıdır? Sorusunun yanıtı için öğrenciler cinsiyetlerine göre tasnif edilmiş ve bağımsız örneklem t-testi kullanılarak analiz gerçekleştirilmiştir. Cinsiyete göre Yaratıcı Problem Çözme Becerisinin Bağımsız örneklem t-testi sonuçları Tablo 5'te verilmiştir.

Tablo 5 .

Kız ve Erkek Ögrencilerin Yaratıcı Problem Çözme Öntest-Sontest Puanlarının Bağımsız Örneklem T-Testi Sonuçları

\begin{tabular}{|c|c|c|c|c|c|c|c|}
\hline Değişken & Grup & $\mathrm{N}$ & $\bar{X}$ & ss & $\mathrm{t}$ & $\mathrm{sd}$ & $\mathrm{p}$ \\
\hline \multirow{2}{*}{ Iraksak düşünme öntest puanı } & $\mathrm{K} 1 \mathrm{z}$ & 30 & 35.56 & 7.43 & \multirow{2}{*}{.344} & \multirow{2}{*}{59} & \multirow{2}{*}{.270} \\
\hline & Erkek & 31 & 34.98 & 5.65 & & & \\
\hline \multirow{2}{*}{ Yakınsak düşünme öntest } & $\mathrm{K} 1 \mathrm{Z}$ & 30 & 29.13 & 5.86 & \multirow{2}{*}{.991} & \multirow{2}{*}{59} & \multirow{2}{*}{.951} \\
\hline & Erkek & 31 & 27.68 & 5.53 & & & \\
\hline \multirow{2}{*}{ Motivasyon öntest } & $\mathrm{K} 1 \mathrm{Z}$ & 30 & 20.75 & 4.61 & \multirow{2}{*}{-.235} & \multirow{2}{*}{59} & \multirow{2}{*}{.323} \\
\hline & Erkek & 31 & 21.03 & 4.69 & & & \\
\hline \multirow{2}{*}{ Çevre öntest } & $\mathrm{K}_{1 \mathrm{Z}}$ & 30 & 40.66 & 11.65 & \multirow{2}{*}{-.745} & \multirow{2}{*}{59} & \multirow{2}{*}{.05} \\
\hline & Erkek & 31 & 42.65 & 8.85 & & & \\
\hline GBB öntest & $\mathrm{K}_{1 \mathrm{Z}}$ & 30 & 15.53 & 4.57 & -1.12 & 59 & .090 \\
\hline
\end{tabular}




\begin{tabular}{|c|c|c|c|c|c|c|c|}
\hline & Erkek & 31 & 16.70 & 3.32 & & & \\
\hline \multirow{2}{*}{$\begin{array}{c}\text { Yaratıcı problem çözme becerisi } \\
\text { öntest } \\
\end{array}$} & $\mathrm{K} 1 \mathrm{z}$ & 30 & 141.65 & 23.30 & \multirow{2}{*}{-.246} & \multirow{2}{*}{59} & \multirow{2}{*}{.857} \\
\hline & Erkek & 31 & 143.04 & 20.63 & & & \\
\hline \multirow{2}{*}{ Iraksak düşünme sontest puanı } & $\mathrm{K} 1 \mathrm{z}$ & 30 & 35.43 & 6.95 & \multirow{2}{*}{-2.34} & \multirow{2}{*}{59} & \multirow{2}{*}{.735} \\
\hline & Erkek & 31 & 39.39 & 6.15 & & & \\
\hline \multirow{2}{*}{ Yakınsak düşünme sontest puanı } & $\mathrm{K} 1 \mathrm{z}$ & 30 & 32.65 & 6.38 & \multirow{2}{*}{-1.63} & \multirow{2}{*}{59} & \multirow{2}{*}{.465} \\
\hline & Erkek & 31 & 35.09 & 5.11 & & & \\
\hline \multirow{2}{*}{ Motivasyon sontest } & $\mathrm{K} 1 \mathrm{z}$ & 30 & 22.03 & 4.74 & \multirow{2}{*}{-.809} & \multirow{2}{*}{59} & \multirow{2}{*}{.860} \\
\hline & Erkek & 31 & 22.98 & 4.44 & & & \\
\hline \multirow{2}{*}{ Çevre sontest } & $\mathrm{K} 1 \mathrm{z}$ & 30 & 39.97 & 8.59 & \multirow{2}{*}{-.627} & \multirow{2}{*}{59} & \multirow{2}{*}{.666} \\
\hline & Erkek & 31 & 41.33 & 8.33 & & & \\
\hline \multirow{2}{*}{ GBB sontest } & $\mathrm{K} 1 \mathrm{z}$ & 30 & 15.62 & 4.03 & \multirow{2}{*}{-1.77} & \multirow{2}{*}{59} & \multirow{2}{*}{.372} \\
\hline & Erkek & 31 & 17.30 & 3.27 & & & \\
\hline \multirow{2}{*}{$\begin{array}{c}\text { Yaratıcı problem çözme becerisi } \\
\text { sontest }\end{array}$} & $\mathrm{K} 1 \mathrm{z}$ & 30 & 145.72 & 23.73 & \multirow{2}{*}{-1.79} & \multirow{2}{*}{59} & \multirow{2}{*}{.573} \\
\hline & Erkek & 31 & 156.11 & 21.13 & & & \\
\hline
\end{tabular}

Tablo 5 incelendiğinde bağımsız örneklem t testi sonuçlarına göre incelenen boyutların öntest-sontest puan farkları arasında anlamlı bir farklılık gözlenmemektedir.

\section{Bilgisayara Yönelik Tutum Öntest-Sontest Sonuçları}

Scratch ile Gerçekleştirilen Dijital Öyküleme Etkinliklerinin Öğrencilerin Bilgisayara yönelik Tutumu Üzerinde Etkisi Var Mıdır? Sorusu için Bilgisayardan Hoşlanma, Bilgisayarın Önemi ve Bilgisayar Kaygısı olmak üzere 3 alt boyuttan oluşan Demir ve Yurdugül (2014) tarafından geliştirilen Ortaokul ve Lise Öğrencileri İçin Bilgisayara Yönelik Tutum Ölçeği kullanılmıştır. Çalışmanın bu aşamasının analizi için hangi testlerin kullanılacağına dair normallik testi yapılmıştır. Ortaya çıkan normallik testinin sonuçları Tablo 6'da verilmiştir.

Tablo 6.

Normallik Testi.

\begin{tabular}{ccccccc}
\hline & \multicolumn{2}{c}{ Kolmogorov-Smirnov } & \multicolumn{3}{c}{ Shapiro-Wilk } \\
\hline & Statistic & $\mathrm{N}$ & $\mathrm{p}$ & Statistic & $\mathrm{N}$ & $\mathrm{p}$ \\
\hline $\begin{array}{c}\text { Bilgisayara Yönelik } \\
\text { Tutum Becerisi Öntest }\end{array}$ & .087 & 61 & .200 & .936 & 61 & .003 \\
\hline $\begin{array}{c}\text { Bilgisayara Yönelik } \\
\text { Tutum Becerisi Sontest }\end{array}$ & .229 & 61 & .000 & .634 & 61 & .000 \\
\hline
\end{tabular}

Tablo 6'ya göre Bilgisayara Yönelik Tutum Ölçeğinin öntest verilerinin normal dağılım gösterdiği söylenebilir ( $\mathrm{p}>0.05)$. Fakat sontest verisi için aynı durumun söz konusu olmadığ 1 görülmektedir $(\mathrm{p}<0.05)$. Bu sonuçtan hareketle testin analizi için non-parametrik testler tercih edilmiştir. Zira Altman (1990), parametrik metotlar için 
her grubun normal dağılım göstermesi gerektiğini belirtmiş; bu durumun sağlanmadığı şartlarda non-parametrik metotların kullanılması gerektiğini vurgulamıştır (Vickers, 2005).

Öğrencilerin uygulama öncesi Bilgisayara Yönelik Tutum Becerisi puanları ile uygulama sonrası Bilgisayara Yönelik Tutum Becerisi puanları arasında anlamlı bir farklılık olup olmadığını test etmek için non-parametrik test olan Wilcoxon Sıralı İşaretler testi uygulanmış, bunun sonucunda ortaya çıkan analizden elde edilen anlamlılık test sonucu Tablo 7'de verilmiştir.

Tablo 7.

Wilcoxon Işaretli Stralar Testi Anlamlılık Test Sonucu

\begin{tabular}{cc}
\hline & Bilgisayardan hoşlanma son test- Bilgisayardan hoşlanma ön test \\
\hline $\mathrm{Z}$ & $-1.676 \mathrm{a}$ \\
\hline $\mathrm{p}$ & .094 \\
\hline $\mathrm{Z}$ & Bilgisayarın önemi son test-Bilgisayarın önemi ön test \\
\hline $\mathrm{p}$ & $-3.939 \mathrm{a}$ \\
\hline $\mathrm{Z}$ & .000 \\
\hline $\mathrm{p}$ & Bilgisayar kaygisı son test-Bilgisayar kaygisı ön test \\
\hline $\mathrm{Z}$ & $-3.546 \mathrm{~b}$ \\
\hline $\mathrm{p}$ & .000 \\
\hline
\end{tabular}

Tablo 7'deki Wilcoxon işaretli sıralar anlamlılık testinin sonucuna göre öğrencilerin Bilgisayardan Hoşlanma sontest ve Bilgisayardan Hoşlanma öntest puanları arasında istatistiksel olarak anlamlı bir fark gözlenmemiştir ( $Z=-1.676$, $\mathrm{p}=.094)$. Öğrencilerin Bilgisayarın Önemi alt boyut öntest ve sontest puanları arasında istatistiksel olarak anlamlı bir fark gözlenmiştir $(Z=-3.939, p=0.000)$. Ayrıca öğrencilerin Bilgisayar Kaygısı alt boyut öntest ve sontest puanları arasında istatistiksel olarak anlamlı bir fark ortaya çıkmıştır $(Z=-3.546, p=0.000)$. Ölçeğin tamamına bakıldığında Öğrencilerin Bilgisayara Yönelik Tutum Becerileri öntest ve sontest puanları arasında istatistiksel olarak anlamlı bir fark görülmemektedir $(\mathrm{Z}=-$ $1.380, \mathrm{p}=.168)$.

\section{Bilgisayara yönelik tutum ölçeğinin sınıf düzeyine göre analizi}

Öğrencilerin sınıf düzeyine göre bilgisayara yönelik tutum becerisi öntest- sontest puanları arasında anlamlı farklılık var mıdır? Sorusunun yanıtı için öğrenciler 6 . ve 7. Sınıflar olarak ayrılmış, ölçeğin tamamı ve her bir boyutu için öntest-sontest puan farkları alınmış ve non-parametrik testlerden olan Mann-Whitney U testi kullanılarak analiz gerçekleştirilmiş ve bunun sonucunda ortaya çıkan analizinden elde edilen anlamlılık test sonucu Tablo 8'de verilmiştir. 
Tablo 8.

Mann-Whitney U Testi Bilgisayardan Hoşlanma Alt Boyutu Sontest-Öntest Puan Farklarının Sinıf Düzeyine Göre Anlamlılık Sonucu

\begin{tabular}{cc}
\hline & Fark \\
\hline Mann-Whitney U & 459.500 \\
Wilcoxon W & 1020.500 \\
Z & -.036 \\
$\mathrm{p}$ & .971 \\
\hline
\end{tabular}

Tablo 8'deki Mann-Whitney U testi sonucuna göre 6. Sınıf öğrencileri ile 7. Sınıf öğrencilerinin Bilgisayardan Hoşlanma sontest puanı ile Bilgisayardan Hoşlanma öntest puanı arasında anlamlı bir fark yoktur $(U=459.500 \mathrm{p}=0.9711, \mathrm{z}=-.036)$.

Bilgisayara Yönelik Tutum Ölçeğinin bir diğer alt boyutu olan Bilgisayarın Önemi alt boyutundan elde edilen sontest ve öntest puan farklarının sınıf düzeyine göre analizi sonucunda elde edilen anlamlılık test sonucu Tablo 9'da verilmiştir.

Tablo 9.

Mann-Whitney U Testi Bilgisayarın Önemi Alt Boyutu Sontest-Öntest Puan Farklarının Sinıf Düzeyine Göre Anlamlılık Sonucu

Fark

Mann-Whitney U

Wilcoxon W

Z

$\mathrm{p}$
382.500

943.500

$-1.157$

.247

Tablo 9'a bakıldığında Mann-Whitney U testi sonucuna göre 6. Sinıf öğrencileri ile 7. Sınıf öğrencilerinin Bilgisayarın Önemi sontest puanı ile Bilgisayarın Önemi öntest puanı arasında anlamlı bir fark yoktur $(U=382.500 \mathrm{p}=0.247, \mathrm{z}=-1.157)$.

Ölçeğin bir diğer alt boyutu olan Bilgisayar Kaygısı alt boyutunun sınıf düzeyine göre analizinden elde edilen anlamlılık test sonucu Tablo 10'da verilmiştir.

Tablo 10.

Mann-Whitney U Testi Bilgisayar Kaygisl Alt Boyutu Sontest-Öntest Puan Farklarının Sinıf Düzeyine Göre Anlamlılık Sonucu

\begin{tabular}{cc}
\hline & Fark \\
\hline Mann-Whitney U & 436.000 \\
Wilcoxon W & 842.000 \\
Z & -.378 \\
p & .706 \\
\hline
\end{tabular}


Tablo 10 incelendiğinde Mann-Whitney U testi sonucuna göre 6. Sınıf öğrencileri ile 7. Sınıf öğrencilerinin Bilgisayar Kaygısı sontest puanı ile Bilgisayar Kaygısı öntest puanı arasında anlamlı bir fark yoktur $(U=436.000 \mathrm{p}=0.706, \mathrm{z}=-0.378)$.

Son aşamada ölçeğin tamamının sontest ve öntest puan farkının sınıf düzeyine göre analizi gerçekleştirilmiştir. Bilgisayara Yönelik Tutum Becerisi Ölçeğinin sontest ve öntest puan farkının sınıf düzeyine göre analizinden elde edilen anlamlılık test sonucu Tablo 11'de verilmiştir.

Tablo 11.

Mann-Whitney U Testi Bilgisayara Yönelik Tutum Becerisi Alt Boyutu SontestÖntest Puan Farklarının Sinıf Düzeyine Göre Anlamlılık Sonucu

\begin{tabular}{cc}
\hline & Fark \\
\hline Mann-Whitney U & 405.000 \\
Wilcoxon W & 966.000 \\
Z & -.826 \\
p & .409 \\
\hline
\end{tabular}

Tablo 11'e bakıldığında Mann-Whitney U testi sonucuna göre 6. Sınıf öğrencileri ile 7. Sınıf öğrencilerinin Bilgisayara Yönelik Tutum Becerisi sontest puanı ile Bilgisayara Yönelik Tutum Becerisi öntest puanı arasında anlamlı bir fark yoktur (U $=405.000 \mathrm{p}=0.409, \mathrm{z}=-.826)$.

\section{Bilgisayara yönelik tutum ölçeğinin cinsiyet düzeyine göre analizi}

Öğrencilerin cinsiyetine göre bilgisayara yönelik tutum becerisi öntest- sontest puanları arasında anlamlı farklılık var mıdır? Sorusunun yanıtı için gerekli analizler yapılmıştır. Bu süreçte öğrenciler kız ve erkek olarak ayrılmış, ölçeğin tamamı ve her bir boyutu için öntest sontest puan farkları alınmış ve non-parametrik testlerden olan Mann-Whitney U testi kullanılarak analiz gerçekleştirilmiştir.

Bilgisayara Yönelik Tutum Becerisi ölçeğinin Bilgisayardan Hoşlanma alt boyutunun cinsiyet düzeyine göre analizinden elde edilen anlamlılık test sonucu Tablo 12 'de verilmiştir.

Tablo 12.

Mann-Whitney U Testi Bilgisayardan Hoşlanma Alt Boyutu Sontest-Öntest Puan Farklarının Cinsiyet Düzeyine Göre Anlamlılık Sonucu

\begin{tabular}{cc}
\hline & Fark \\
\hline Mann-Whitney U & 429.500 \\
Wilcoxon W & 925.500 \\
Z & -.515 \\
P & .607 \\
\hline
\end{tabular}


Tablo 12'deki Mann-Whitney U testi sonucuna göre k1z öğrenciler ile erkek öğrencilerin Bilgisayardan Hoşlanma sontest puanı ile Bilgisayardan Hoşlanma öntest puanı arasında anlamlı bir farklılık bulunamamıştır $(U=429.500 \mathrm{p}=0.607, \mathrm{z}=-.515)$.

Bilgisayara Yönelik Tutum Ölçeğinin bir diğer alt boyutu olan Bilgisayarın Önemi alt boyutundan elde edilen sontest ve öntest puan farklarının cinsiyet düzeyine göre analizi sonucunda elde edilen anlamlılık test sonucu Tablo 13'te verilmiştir.

Tablo 13

Mann-Whitney U Testi Bilgisayarın Önemi Alt Boyutu Sontest-Öntest Puan Farklarının Cinsiyet Düzeyine Göre Anlamlılık Sonucu

\begin{tabular}{cc}
\hline & Fark \\
\hline Mann-Whitney U & 400.500 \\
Wilcoxon W & 896.500 \\
Z & -.935 \\
P & .350 \\
\hline
\end{tabular}

Tablo 13 incelendiğinde Mann-Whitney U testi sonucuna göre k1z öğrenciler ile erkek öğrencilerin Bilgisayardan Hoşlanma sontest puanı ile Bilgisayardan Hoşlanma öntest puanı arasında anlamlı bir farklılık ortaya çıkmamıştır $(\mathrm{U}=400.500 \mathrm{p}=0.350$, $\mathrm{z}=-.935)$.

Bilgisayara Yönelik Tutum Ölçeğinin bir diğer alt boyutu olan Bilgisayar Kaygısı alt boyutundan elde edilen sontest ve öntest puan farklarının cinsiyet düzeyine göre analizi sonucunda elde edilen anlamlılık test sonucu Tablo 14'de verilmiştir.

Tablo 14.

Mann-Whitney U Testi Bilgisayar Kaygisı Alt Boyutu Sontest-Öntest Puan

Farklarının Cinsiyet Düzeyine Göre Anlamlılık Sonucu

\begin{tabular}{cc}
\hline & Fark \\
\hline Mann-Whitney U & 433.000 \\
Wilcoxon W & 929.000 \\
Z & -.464 \\
p & .643 \\
\hline
\end{tabular}

Tablo 14'e bakıldığında Mann-Whitney U testi sonucuna göre kız öğrenciler ile erkek öğrencilerin Bilgisayar Kaygısı sontest puanı ile Bilgisayar Kaygısı öntest puanı arasında anlamlı bir farklılık ortaya çıkmamıştır $(U=433,000 \mathrm{p}=0,643, \mathrm{z}=-, 464)$.

Bu bölümün son aşamasında ölçeğin tamamının sontest ve öntest puan farkının cinsiyet düzeyine göre analizi sağlanmıştır. Ortaya çıkan anlamlılık test sonucu Tablo 15 'te gösterilmiştir. 
Tablo 15 .

Mann-Whitney U Testi Bilgisayara Yönelik Tutum Becerisi Alt Boyutu SontestÖntest Puan Farklarının Cinsiyet Düzeyine Göre Anlamlılı Sonucu

\begin{tabular}{cc}
\hline & Fark \\
\hline Mann-Whitney U & 416.000 \\
Wilcoxon W & 912.000 \\
Z & -.708 \\
$\mathrm{p}$ & .479 \\
\hline
\end{tabular}

Tablo 15 göstermektedir ki Mann-Whitney U testi sonucuna göre k1z öğrenciler ile erkek öğrencilerin Bilgisayara Yönelik Tutum Becerisinin sontest puanı ile Bilgisayara Yönelik Tutum Becerisinin öntest puanı arasında anlamlı bir farklılık ortaya çıkmamıştır ( $\mathrm{U}=416.000 \mathrm{p}=0.479, \mathrm{z}=-.708)$.

\section{Öğrencilerin Scratch İle Programlamaya Dair Görüşleri}

$\mathrm{Bu}$ bölümde 61 öğrencinin olduğu örneklem grubu içerisinden rastgele 10 öğrenci seçilmiş, yarı yapılandırılmış görüşme formu aracılığıyla görüşleri alınmış ayrıca bu deneyim ses kaydı ile kaydedilmiştir. Bu süreçte ses kayıt cihazı kullanılması verilerin eksik veya hatalı olma olasılığını önemli ölçüde ortadan kaldırmıştır. Görüşme formunda yer alan sorular, gerçekleştirilen çalışma kapsamında Scratch ile programlamaya dair görüşlere, dijital öyküleme yaparken Scratch programın kullanımına yönelik görüşlere, Dijital Öykülemenin Scratch ile programlamaya etkisine yönelik olmak üzere üç kategoride incelenmiştir.

Öğrencilerin Scratch ile Programlamaya dair görüşleri tablo 16'da verilmiştir.

Tablo 16.

Öğrencilerin Scratch Ile Programlamaya Dair Görüşleri

\begin{tabular}{|c|c|}
\hline Görüşme Soruları & $\mathrm{f}$ \\
\hline \multicolumn{2}{|c|}{$\begin{array}{l}\text { Deneyimlediğiniz uygulamayı beğenip faydalı buldunuz mu; deneyimlediğiniz uygulama size neler } \\
\text { kazandırdı? }\end{array}$} \\
\hline Bilgisayar anlayışı & 5 \\
\hline Hayal gücü & 4 \\
\hline Sinırsızlık & 4 \\
\hline Fikir edinme & 1 \\
\hline Toplam & 14 \\
\hline
\end{tabular}

$\mathrm{Bu}$ süreçte görüşme sağlanan öğrencilerin hepsi uygulamayı beğendiğini ve faydalı bulduklarını ifade etmiştir. Ayrıca öğrencilere uygulamaya ve kazanımlarına yönelik görüşleri sorulduğunda hepsi uygulamaya dair olumlu görüş bildirmiştir. 5 öğrenci uygulamanın bilgisayar anlayışını, bilgisayara dair düşüncelerini değiştirdiğini, bilgisayarın daha başka, önemli amaçlar için kullanılabileceğini ifade etmiştir. Bu ifadeleri destekleyen örnek öğrenci görüşleri aşağıdaki gibidir. 
“Kodlamayı öğrenmeme yardımcı oldu. Bilgisayarı ilk kez bu şekilde kullanmamı sağladl.”(Ö3).

"Problemleri kodlama yaparak çözmemin yanında bilgisayarı daha iyi kullanmamı sağladı.” (Ö2).

4 öğrenci hayal gücüne vurgu yapıp, kodlama konusunda bilgi birikim sağlayıp fikir edindiğini ifade etmiştir. Bu ifadeleri destekleyen örnek öğrenci görüşü aşağıdaki gibidir.

“Hayal gücümün dlşa vurumunun mümkün olduğunu gördüm. Bilgisayar kodlamanın temelini ögrendim.” (Ö5).

4 öğrenci programın akla gelebilecek her şeyi yapabilmeye olanak sağladığına, yapabileceklerinin sınırı olmadığına vurgu yapmıştır. Bu ifadeleri destekleyen örnek öğrenci görüşü aşağıdaki gibidir.

"Eskiden çizgi filmler ve animasyonların nasıl yapıldığını merak ederdim. Şimdi onlara benzer ve aklıma gelebilen her türlü çalışmayı yapabiliyorum.” (Ö1).

1 öğrenci ise bilmediği ve öğrenmek istediği konular hakkında fikir edindiğini, ileride yazılım mühendisi olmak istediğini bu yüzden bu uygulamanın yazılım mesleği ile ilgili güzel fikirler kazandırdığını ifade etmiştir. Bu ifadeleri destekleyen örnek öğrenci görüşü aşağıdaki gibidir.

"Illeride yazılım mühendisi olmak istediğim için bana kodlamanın temellerini ögretti. Yazılım mühendisliği ile ilgili fikir edinmemi să̆ladı.”(Ö9).

\section{Öğrencilerin dijital öyküleme yaparken scratch programının kullanımına yönelik görüşleri}

Görüşme sürecinde ilgili soru öğrencilere yöneltilmiş ve gelen yanıtlar kaydedilmiştir. Öğrencilerin Scratch Programının Kullanımına Yönelik Görüşleri Tablo 17'de verilmiştir.

Tablo 17.

Ögrencilerin Dijital Öyküleme Yaparken Scratch Programının Kullanımına Yönelik Görüşleri

Görüşme Soruları f

Dijital Öyküleme Yaparken Scratch Programının Kullanımına Yönelik Görüşleriniz Nelerdir?

Kullanım Kolaylığı

İlgi Çekici Olması

Eğlenceli 3

Toplam 14


Tablo 17 incelendiğinde öğrencilerin dijital öyküleme yaparken scratch programının kullanımına yönelik görüşlerini programın kullanım kolaylığı, ilgi çekici ve eğlenceli olması gibi faktörlerin etkilediği görülmektedir.

7 öğrencinin kullanım kolaylığı faktörünü vurguladığı ortaya çıkmıştır. Bu ifadeleri destekleyen örnek öğrenci görüşü aşağıdaki gibidir.

“Gayet güzel bir program. Karmaşık yapıları daha kolay yollardan yapmamızı sağllyor.” (Ö8).

"Kolay, kullanışlı, anlaşılır, kurguladı̆̆ım şeyleri yapmamı să̆layan bir program.” (Ö1).

4 öğrenci, programı ilgi çekici bulduğunu ifade etmiştir. Bu ifadeleri destekleyen örnek öğrenci görüşü aşağıdaki gibidir.

“Kendi fikrimizi, özgünlüğümüzü yansıtabildiğimiz, kullanıcı dostu, ilgi çekici bir program olduğunu kavradım.” (Ö10).

"Öğretici ve ilgi çekici bir program. İstediğim her şeyi yapabilmeme yardımcl olacağına inanıyorum.” (Ö4).

3 öğrenci, programı eğlenceli bulduğunu ifade etmiştir. Bu ifadeleri destekleyen örnek öğrenci görüşü aşağıdaki gibidir. (Ö6).

“ilk başlarda zor gelmişti fakat ögrendikçe kolaylaştı ve eğlenceli bir hal aldı."

\section{Dijital öyküleme tekniğinin scratch ile programlamaya etkisi}

Öğrencilerin Dijital Öyküleme Tekniğinin Scratch ile Programlamaya Etkisine yönelik görüşleri Tablo 18'de verilmiştir.

Tablo 18.

Ögrencilerin Dijital Öyküleme Tekniğinin Scratch İle Programlamaya Etkisine Yönelik Görüşleri

\begin{tabular}{cc}
\hline Görüşme Soruları & $\mathrm{f}$ \\
\hline Dijital Öyküleme Tekniğinin Scratch ile Programlamaya Etkisi Sizce Nasıldır? \\
Faydalılık & 5 \\
Eğitsellik & 5 \\
İşlevsellik & 3 \\
\hline Toplam & 13 \\
\hline
\end{tabular}

Tablo 18 incelendiğinde öğrencilerin dijital öyküleme tekniğinin Scratch ile programlamaya etkisine yönelik görüşlerini faydalılık, eğitsellik ve işlevsellik gibi faktörlerin etkilediği görülmektedir. 
5 öğrencinin Dijital Öyküleme Tekniğinin Scratch programlama ile birleşmesi sonucu daha faydalı ve bütüncül projeler ortaya çıktığını ifade ettikleri görülmektedir. $\mathrm{Bu}$ ifadeleri destekleyen örnek öğrenci görüşü aşağıdaki gibidir.

"Problemleri daha bütüncül yollardan ele almamızı sağlayıp daha tamamlayıcı projeler yapmamızı sağladı.”(Ö5).

"Dikkatimi ve bütüncül düşünmemi teşvik etti bu yöntem. Dijital öyküleme ve Scratch'in bir araya gelmesi faydalı ve başarllı." (Ö7).

5 öğrencinin Dijital Öyküleme Tekniğinin Scratch ile birleşiminin Daha eğitsel ve eğlenceli sonuçlar ortaya çıkmasını sağladığına yönelik görüşleri öne çıkmaktadır. Bu ifadeleri destekleyen örnek öğrenci görüşü aşağıdaki gibidir.

"Çok fazla etkisi var. Scratch ile Dijital Öyküleme bir araya gelince daha eğitsel ve keyifli sonuçlar ortaya çıkıyor." (Ö4).

"Kodlamayı animasyon gibi bir hale getirmemizi sağlayarak onu basitlikten kurtarlyor. Oldukça güzel ve heyecan verici." (Ö9).

3 öğencinin ise Dijital Öyküleme Tekniğinin Scratch ile birleşiminin daha anlaşılır ve işlevsel sonuçların ortaya çıkmasını sağladığına yönelik görüşlerini görmekteyiz. $\mathrm{Bu}$ ifadeleri destekleyen örnek öğrenci görüşü aşağıdaki gibidir.

"Daha anlaşllır olmasını sağladl. Her şey tek bir sahne veya kareye hapsetmek yerine dijital öyküleme ile daha uzun ve yerli yerinde bir etki ve sonuç sağladı." (Ö1).

"Dijital Öyküleme Scratch ile daha detaylı sonuçların mümkün olabileceğini gösterdi. Olumlu buldum." (Ö8).

\section{Tartışma, Sonuç ve Öneriler}

Scratch ile gerçekleştirilen dijital öyküleme etkinliklerinin öğrencilerin yaratıcı problem çözme becerilerine etkisini tespit etmek amacıyla yapılan bu araştırmada uygulanan eğitim programının öğrencilerin yaratıcı problem çözme becerileri üzerinde anlamlı farklılaşmayı ortaya koyduğu sonucuna ulaşılmıştır. Bulgular ışı̆̆ında yaratıcı problem çözme envanteri faktörleri ıraksak düşünme, yakınsak düşünme, motivasyon, çevre ve gbb incelendiğinde rraksak düşünme, yakınsak düşünme ve motivasyon faktörlerinde anlamlı farklılaşma olduğu gözlemlenmekte; çevre ve gbb faktörlerinde anlamlı bir farklılık olmadığı görülmektedir. Bu sonuçlara göre Scratch ile gerçekleştirilen dijital öyküleme etkinliklerinin öğrencilerin yaratıcı problem çözme becerileri, yakınsak düşünme, rraksak düşünme ve motivasyon üzerinde etkili olduğu söylenebilir. Elde edilen bu sonuç litaratürle uyumluluk göstermektir. Örneğin Vidal (2010) tarafindan yapılan bir çalışmanın sonucunda katılımcıların yaratıcı problem çözme becerilerinin çalışma öncesi duruma göre farklılaştığı deneyimlenmiştir. Başka bir çalışmada Phaksunchai, Kaemkate and Wongwanich (2014), katılımcılara yaratıcı problem çözme becerisini geliştirmeyi 
hedefleyen bir süreç deneyimletmiş, süreç sonunda katılımcıların yaratıcı problem çözme becerilerinde puan artışlarını gözlemlemiştir. Bir diğer çalışmada Dumas, Schmidt and Alexander (2016) tarafindan yapılan deneysel bir çalışma sonucunda katılımcıların uygulama öncesi ve sonrası yaratıcı problem çözme becerileri arasında farklılık olduğu kaydedilmiştir. Yaratıcı Problem Çözme becerisine dair Chanayotha and Na-songkhla (2015) tarafindan gerçekleştirilen bir çalışmanın sonuçları, süreç sonunda Yaratıcı Problem Çözme becerisi puanının artışı vurgulanmıştır.

Uygulanan eğitim programının öğrencilerin yaratıcı problem çözme becerilerinin sınıf düzeyine göre etkisini saptamak amacıyla yapılan ölçümde 6. ve 7. Sinıf öğrencileri arasında yalnızca Çevre faktörü öntest ve Yaratıcı Problem Çözme Becerileri Öntest boyutunda anlamlı farklılık görülmüştür. Ölçeğin diğer faktörlerinin öntest ve sontest puanlarına göre sınıf düzeyinde anlamlı farklılık ortaya çıkmamıştır. $\mathrm{Bu}$ sonuçlara binaen, uygulanan eğitim programının sınıf düzeyine göre farklılık ortaya koymakta etkili olduğu söylenemez.

Öğrencilerin Scratch ile programlamaya dair görüşlerinin derlendiği ölçümde görüşmeye katılan tüm öğrencilerin Scratch ile programlama deneyimini beğenip faydalı buldukları kaydedilmiştir. Öğrencilerden gelen yanıtların çözümlenmesi sonucunda uygulanan eğitim programının, öğrencilere bilgisayar anlayışı, hayal gücünü daha derin kullanma, yapılabileceklerin sinırsız olması ve temel konularda fikren bilgi sahibi yapma gibi faydalılıklarıyla ön plana çıktığı görülmüştür. Bu bakımdan öğrencilerin Scratch ile programlama deneyimini beğenip, etkili buldukları sonucuna ulaşılabilir. Bu sonuç, Sáez-López, Román-González and Vázquez-Cano (2016)'nın araştırma sonuçlarıyla benzerlik göstermektedir.

Uygulanan eğitim programının öğrencilerin yaratıcı problem çözme becerilerinin cinsiyet düzeyine göre etkisini ortaya koymak amacıyla yapılan ölçümde, alt faktörlerde ve ölçeğin tümü kapsamında istatistiksel olarak anlamlı bir farklılık görülmemektedir. Bu gerçeklikten hareketle, uygulanan eğitim programının hedef kitlenin cinsiyeti üzerinde bir fark ortaya koymakta etkili olduğu ileri sürülemez.

Öğrencilerin Dijital Öyküleme çalışması esnasında Scratch programının kullanımına yönelik görüşlerinin derlendiği ölçümde öğrencilerin uygulamayı kolay, anlaşılır, ilgi çekici buldukları görülmektedir. Bu sonuçlar uygulamanın ve eğitim sürecinin öğrenciler tarafindan benimsendiğine, öğrenciler için hazırlanan eğitim programının sıradanlıktan uzak, zevkli, eğlenceli ve öğretici geçtiğine işaret edebilmektedir. Bunun yanı sıra bu sonuç, Ouahbi, Kaddari, Darhmaoui, Elachqar and Lahmine (2015) tarafından gerçekleştirilen çalışma sonuçları ile uyumluluk göstermektedir.

Öğrencilerin dijital öyküleme tekniğinin Scratch ile programlamaya etkisine yönelik görüşlerinin ele alındığı boyutta öğrenciler, uygulamayı faydalılık, eğitsellik, işlevsellik gibi faktörlerin etkilediği görülmektedir. Öğrenciler sürecin, faydalılık olarak daha bütüncül, birbirini tamamlayan projelerin ortaya çıktığını, eğitsel olarak 
daha eğlenceli ve öğretici, işlevsellik olarak daha detaylı ve derinleştirilebilir sonuçlar ortaya çıkardığına dair görüş bildirmiştir. Bu sonuçlar, dijital öykülemenin Scratch ile programlama ile daha zenginleştiği, daha kolaylaştığı, daha etkili ve anlaşılır bir boyut kazandığı şeklinde yorumlanabilir. Bu çıkarsamanın Sylla, Coutinho, Branco and Müller (2015)'in araştırma sonuçlarıyla paralellik gösterdiği söylenebilir.

Çalışmanın sonuçları 1şı̆̆ında gelecek araştırmalar için hem uygulama hem de araştırma yapıcılara şu öneriler yapılabilir:

Uygulama yapıcılara öneriler:

> Öğretmenler dijital öyküleme öğretim materyalleri geliştirebilmeleri için cesaretlendirilmeli ve bu konuda yetkinlik kazabilmeleri için eğitimler almalıdır.

$>$ Scratch proje havuzu Scratch programının hedef kitlesi içerisinde bulunan öğrencilere tanıtılmalı, öğrenciler bu havuza katkı sağlamak için cesaretlendirilmelidir.

$>$ Öğrencilerin yaratıcı problem çözme becerileri, Scratch ile programlama ve dijital öyküleme yöntemi aracılığıyla daha kapsamlı eğitim programları ile geliştirilebilmelidir.

Araştırma yapıcılara öneriler:

$>$ Dijital öyküleme ve programlama öğretimi ile ortaya çıkan materyalin hangi disiplinlerde daha etkili olarak kullanılabileceği araştırılabilir.

$>$ Dijital öyküleme ve programlama öğretimi ile ortaya çıkan materyalin eğitim programlarında yer alıp alamayacağı araştırılabilir.

$>$ Öğreticilerin dijital öyküleme ve programlama öğretimi ile ortaya çıkan materyale yönelik tutumları araştırılabilir.

> Farklı alanlarda ve farklı yaş aralığındaki öğrencilerle dijital öyküleme ile ilgili çalışmalar yapılabilir.

\section{Çıkar Çatışması ve Etik Bildirimi}

Yazarlar arasında herhangi bir çıkar çatışması bulunmadığı ve yazarların çalışmaya eşit katkı sağladığı beyan edilmiştir. Ayrıca yazarların etik kurallara bağlılığını gösterir rapor, ilgili üniversitenin Eğitim Bilimleri Birim Etik kurulunun 06.05.2020 tarihli toplantıda alınan 12 nolu kararla belgelenmiştir.

\section{Kaynakça}

Alkan, C. (2011). Eğitim Teknolojisi. Ankara: Anı Yayınc1lık.

Altman, D. G. (1990). Practical statistics for medical research. CRC press.

Akyuz, S., \& Yavuz, F. (2015). Digital learning in EFL classrooms. Procedia-Social and Behavioral Sciences, 197, 766-769. doi: 10.1016/j.sbspro.2015.07.176 
Baran-Bulut, D., İpek, A. S., \& Aygün, B. (2018). Yaratıcı problem çözme özellikleri envanterini Türkçeye uyarlama çalışması. Abant İzzet Baysal Üniversitesi Eğitim Fakültesi Dergisi, 18(3), 1360-1377.

Büyüköztürk, Ş., Çakmak, E. K., Akgün, Ö. E., Karadeniz, Ş., \& Demirel, F. (2016). (21. baskı) Bilimsel Araştırma Yöntemleri. Ankara: Pegem Akademi. doi: 10.14527/9789944919289

Chanayotha, P., \& Na-songkhla, J. (2015). Development of the open educational rajabhat university students resources using service learning to enhance public consciousness and creative problem solving. Procedia-Social anfiçerid Behavioral Sciences, 174, 1976-1982. doi: 10.1016/j.sbspro.2015.01.863

Demir, Ö., \& Yurdugül, H. (2014). Ortaokul ve lise öğrencileri için bilgisayara yönelik tutum ölçeğinin Türkçe'ye uyarlanmas1. Eğitim ve Bilim, 39(176). doi: 10.15390/EB.2014.3619

Dumas, D., Schmidt, L. C., \& Alexander, P. A. (2016). Predicting creative problem solving in engineering design. Thinking Skills and Creativity, 21, 50-66. doi: 10.1016/j.tsc.2016.05.002

Gülbahar, Y. (2019). (5. baskı) E-öğrenme. Ankara: Pegem Akademi. doi: $10.14527 / 9786054282098$

Hooshyar, D., Binti Ahmad, R., Wang, M., Yousefi, M., Fathi, M., \& Lim, H. (2018). Development and evaluation of a game-based Bayesian intelligent tutoring system for teaching programming. Journal of Educational Computing Research, 56(6), 775-801. doi: $10.1177 / 0735633117731872$

Lin, C. Y. (2010). Analyses of Attribute Patterns of Creative Problem Solving Ability among Upper Elementary Students in Taiwan. ProQuest LLC. 789 East Eisenhower Parkway, PO Box 1346, Ann Arbor, MI 48106.

Nelson, J. (2009). Celebrating scratch in libraries: creation software helps young people develop 21st-century literacy skills. School Library Journal, 20-21.

OECD (2017), PISA 2015 results (volume v): collaborative problem solving, PISA, OECD Publishing, Paris. doi: 10.1787/9789264285521-en

Ouahbi, I., Kaddari, F., Darhmaoui, H., Elachqar, A., \& Lahmine, S. (2015). Learning basic programming concepts by creating games with scratch programming environment. Procedia-Social and Behavioral Sciences, 191, 1479-1482. doi: 10.1016/j.sbspro.2015.04.224

Pemberton, J. R., Borrego, J., \& Cohen, L. M. (2006). Using interactive computer technology to enhance learning. Teaching of Psychology, 33(2), 145-147. doi: 10.1207/s15328023top3302_9

Peng, G. (2017). Do computer skills affect worker employment? An empirical study from CPS surveys. Computers in Human Behavior, 74, 26-34. doi: 10.1016/j.chb.2017.04.013 
Phaksunchai, M., Kaemkate, W., \& Wongwanich, S. (2014). Research and development of a training package for developing creative problem solving of undergraduate students. Procedia-Social and Behavioral Sciences, 116, 4824-4828. doi: 10.1016/j.sbspro.2014.01.1032

Prensky, M. (2001). Digital natives, digital immigrants part 1. On the horizon, 9(5), 1-6.

Revathi, A., \& M, Shwettha. (2019). Digital learning. CSI Communication. 21-23.

Robin, B. R. (2015). The effective uses of digital storytelling as a teaching and learning tool. Handbook of research on teaching literacy through the communicative and visual arts, 2, 429-440.

Sáez-López, J. M., Román-González, M., \& Vázquez-Cano, E. (2016). Visual programming languages integrated across the curriculum in elementary school: A two year case study using "Scratch" in five schools. Computers \& Education, 97, 129-141. doi: 10.1016/j.compedu.2016.03.003

Sadik, A. (2008). Digital storytelling: A meaningful technology-integrated approach for engaged student learning. Educational technology research and development, 56(4), 487506. doi: $10.1007 / \mathrm{s} 11423-008-9091-8$

Sylla, C., Coutinho, C., Branco, P., \& Müller, W. (2015). Investigating the use of digital manipulatives for storytelling in pre-school. International Journal of Child-Computer Interaction, 6, 39-48. doi: 10.1016/j.ijcci.2015.10.001

Teo, T. (2006). Attitudes toward computers: A study of post-secondary students in Singapore. Interactive Learning Environments, 14(1), 17-24. doi: 10.1080/10494820600616406

Teo, T. (2008). Assessing the computer attitudes of students: An Asian perspective. Computers in Human Behavior, 24, 1634-1642. doi: 10.1016/j.chb.2007.06.004

Vickers, A. J. (2005). Parametric versus non-parametric statistics in the analysis of randomized trials with non-normally distributed data. BMC medical research methodology, 5(1), 35. doi: $10.1186 / 1471-2288-5-35$

Wang, C. H., \& Lin, H. C. K. (2018). Constructing an affective tutoring system for designing course learning and evaluation. Journal of Educational Computing Research, 55(8), 11111128. doi: $10.1177 / 0735633117699955$ 


\section{Extended Abstract}

Nowadays, one of the skills that are emphasized by many authorities is Creative Problem Solving. This skill is one of the most deprivation experienced of students in international tests such as PISA or many national tests in Turkey. Because of Turkey in terms of creative problem-solving skill are below from the OECD average as well as being in last places among OECD countries according to PISA 2015 results. The low level of problem-solving skills and inability to develop solutions to problems from different and creative perspectives can cause individuals to have difficultly in solving the problems they face.

Many researchers believe that integrating ICT (Information and Communication Technology) in education improves students' thinking and cognitive process capabilities (Teo, 2006). Computer technology is seen as an important tool that effectively supports the way of learning and teaching. It's also true that computer technology has the potential to develop students' abilities such as collaboration, communication, problem-solving, and lifelong learning. For example a study by Pemberton et al., (2006) revealed that using interactive computer technologies in education increases students' learning outcomes and this method not only provides strong learning environments, but also motivates students to learn and participate in classroom activities. Accordingly students' attitude towards computer has an important role in accepting the computer as a learning tool and in accepting the computer indispensable for their future studies. Developing a positive attitude towards the computer will facilitate the present and future social and professional lives of individuals as well as the acquisition of highly important skills. Therefore, computer attitude should be considered as a key fact in individuals' use of technology and accept of Computer as a learning tool.

Moreover, thanks to the advancement of technology and innovative movements, it is possible to observe a great change at every level of society. It is a fact that classroom environments and education are also affected by this change. Accordingly, new terms are emerging in every discipline. One of the terms that arised with the effect of technology in the education world is Digital Learning (Akyuz \& Yavuz, 2015). Digital Learning is simply a kind of learning that is carried out with the opportunities brought by technology, apart from traditional learning and teaching tools (Revathi \& Shwettha, 2019). Digital learning gives all students learning experience. Strengthens or provides learning about any subject. It also helps to create a differentiation in the traditional process of the education system.

In this study, it is aimed to investigate the effect of digital storytelling that performed with Scratch on students' creative problem-solving skills and their attitudes towards computers. The research was designed according to one group pretest-posttest design which is one of the weak experimental designs. For this study convenience sampling was employed, and the study was conducted with 61 secondary school students who are secondary school students at a private school. The students who 
participated in the study were given the necessary information in the first week. Later, the Creative Problem-Solving Properties Inventory, which was developed by BaranBulut et al. (2018), was used to measure student's attitude towards computer and the second survey developed by Demir \& Yurdugül (2014) was employed as a pretest. In the five-week practice, the students first drafted storytelling on paper identical with the curriculum of the English lesson each week. And then transferred them to digital media with the help of Scratch. At the end of the study, the same scales -that is the say developed by Baran-Bulut et al. (2018) and Demir \& Yurdugül (2014)-were applied as posttest and the study was completed. Quantitative data in the study were collected 5 sub-dimension as divergent thinking, convergent thinking, motivation, environment and general knowledge skills in creative problem-solving skills. On the other hand it was collected 3 sub-dimension as computer enjoyment, computer importance and computer anxiety in attitude towards computer skills. Accordingly parametric and non-parametric tests were used for the analysis of quantitative data.

According to the findings, a statistically significant difference was found between the pre-test and post-test scores of creative problem-solving in favor of posttest. Moreover, the findings in the sub-dimensions of the scale revealed that there was a significant difference between pre-test and post-test scores of Divergent Thinking, Convergent Thinking and Motivation in favor of posttest. Moreover, statistical significant difference was not found between the pretest-posttest scores of the dimensions of Environment and General Knowledge and Skills. As a result, it can be said that digital storytelling with Scratch has an effect on students' creative problemsolving skills, convergent thinking, divergent thinking and motivation.

On the other hand it is observed that this study revealed significant differences in the importance of computer and computer anxiety sub-factors. It cannot be said that there is a significant difference between computer enjoyment and attitude skills towards the computer which defines the whole scale. In this case, it can be said that the study changed the attitudes of students on computer importance and computer anxiety. 